University of Nebraska - Lincoln

DigitalCommons@University of Nebraska - Lincoln

$10-27-2006$

\title{
The Legacy of Leaded Gasoline in Bottom Sediment of Small Rural Reservoirs
}

Kyle E. Juracek

U.S. Geological Survey

Andrew C. Ziegler

U.S. Geological Survey

Follow this and additional works at: https://digitalcommons.unl.edu/usgsstaffpub

Part of the Earth Sciences Commons

Juracek, Kyle E. and Ziegler, Andrew C., "The Legacy of Leaded Gasoline in Bottom Sediment of Small Rural Reservoirs" (2006). USGS Staff -- Published Research. 22.

https://digitalcommons.unl.edu/usgsstaffpub/22

This Article is brought to you for free and open access by the US Geological Survey at DigitalCommons@University of Nebraska - Lincoln. It has been accepted for inclusion in USGS Staff -- Published Research by an authorized administrator of DigitalCommons@University of Nebraska - Lincoln. 


\title{
The Legacy of Leaded Gasoline in Bottom Sediment of Small Rural Reservoirs
}

\author{
Kyle E. Juracek* and Andrew C. Ziegler
}

\begin{abstract}
The historical and ongoing lead $(\mathrm{Pb})$ contamination caused by the 20th-century use of leaded gasoline was investigated by an analysis of bottom sediment in eight small rural reservoirs in eastern Kansas, USA. For the reservoirs that were completed before or during the period of maximum $\mathrm{Pb}$ emissions from vehicles (i.e., the 1940s through the early 1980s) and that had a major highway in the basin, increased $P b$ concentrations reflected the pattern of historical leaded gasoline use. For at least some of these reservoirs, residual $\mathrm{Pb}$ is still being delivered from the basins. There was no evidence of increased $\mathbf{P b}$ deposition for the reservoirs completed after the period of peak $\mathbf{P b}$ emissions and (or) located in relatively remote areas with little or no highway traffic. Results indicated that several factors affected the magnitude and variability of $\mathbf{P b}$ concentrations in reservoir sediment including traffic volume, reservoir age, and basin size. The increased Pb concentrations at four reservoirs exceeded the U.S. Environmental Protection Agency threshold-effects level $\left(30.2 \mathrm{mg} \mathrm{kg}^{-1}\right)$ and frequently exceeded a consensus-based threshold-effects concentration (35.8 $\mathrm{mg} \mathrm{kg}^{-1}$ ) for possible adverse biological effects. For two reservoirs it was estimated that it will take at least 20 to $70 \mathrm{yr}$ for $\mathrm{Pb}$ in the newly deposited sediment to return to baseline (pre-1920s) concentrations $\left(30 \mathrm{mg} \mathrm{kg}^{-1}\right.$ ) following the phase out of leaded gasoline. The buried sediment with elevated $\mathrm{Pb}$ concentrations may pose a future environmental concern if the reservoirs are dredged, the dams are removed, or the dams fail.
\end{abstract}

L $\operatorname{EAD}(\mathrm{Pb})$ is an important environmental contaminant because of its known toxicity to humans and other living organisms (Forstner and Wittmann, 1981; Adriano, 2001). Over the past century, a major source of $\mathrm{Pb}$ in the environment was particulate emissions from vehicles. The $\mathrm{Pb}$ originated from the combustion of leaded gasoline, which was introduced in the 1920s and quickly became standard (Davies, 1990). From 1941 to 1970 in the USA, $\mathrm{Pb}$ consumption by the gasoline industry increased $457 \%$ from 45350 to 252600 metric tons (Forstner and Wittmann, 1981). During the period of maximum leaded gasoline use (i.e., the 1940s through the early 1980s), vehicle emissions became the predominant source of $\mathrm{Pb}$ to the environment. For example, in 1970, total national emissions of $\mathrm{Pb}$ from vehicles accounted for about $80 \%$ of all emissions and were about 570 times greater than the total $\mathrm{Pb}$ emissions from coal-fired powerplants (USEPA, 2000).

Use of leaded gasoline increased until its phase out, legislated by the Clean Air Act of 1970, began in the 1970s. The subsequent rapid decline in gasoline $\mathrm{Pb}$ con-

U.S. Geological Survey, 4821 Quail Crest Place, Lawrence, KS 660493839. Received 30 Mar. 2006.*Corresponding author (kjuracek@ usgs.gov).

Published in J. Environ. Qual. 35:2092-2102 (2006). Technical Reports: Heavy Metals in the Environment doi:10.2134/jeq2006.0128 sumption in the USA was estimated to be about $75 \%$ from 1975 to 1985 (Alexander and Smith, 1988). From 1970 to 1990 , total national $\mathrm{Pb}$ emissions from vehicles decreased an estimated 99.8\% (USEPA, 2000). Total national $\mathrm{Pb}$ emissions from all sources for 1900 through 1998 , as well as total emissions from on-road vehicles for selected years, are shown in Fig. 1.

Numerous studies have documented increased $\mathrm{Pb}$ concentrations in air, soil, and vegetation located near streets and highways (e.g., Cannon and Bowles, 1962; Daines et al., 1970; Lagerwerff and Specht, 1970; Motto et al., 1970). Lead concentrations decrease rapidly in air, soil, and vegetation with distance from streets and highways and in soils with depth in the soil profile (Singer and Hanson, 1969; Daines et al., 1970; Lagerwerff and Specht, 1970; Milberg et al., 1980). Lead concentrations also are affected by prevailing wind directions (Cannon and Bowles, 1962; Page et al., 1971; Milberg et al., 1980). While much of the environmental $\mathrm{Pb}$ contamination from vehicular emissions was concentrated near the sources, long-distance atmospheric transport also has been documented (Boutron et al., 1991; Barrie et al., 1992; Outridge et al., 2002).

Once introduced into the environment, $\mathrm{Pb}$ may be transported to lakes and reservoirs via direct atmospheric deposition or by a terrestrial pathway. The terrestrial pathway involves the attachment of $\mathrm{Pb}$ to soil particles that are subsequently eroded and transported to lakes and reservoirs by fluvial processes. Bottom sediments within lakes and reservoirs serve as a sink for $\mathrm{Pb}$ and also may serve as a source of $\mathrm{Pb}$ to the overlying water column and biota (Baudo et al., 1990; Zoumis et al., 2001).

Previous studies have documented changes in the deposition of $\mathrm{Pb}$ in bottom sediment attributed to human activity. For example, Crecelius and Piper (1973) and Bertine and Mendeck (1978) documented an increase in $\mathrm{Pb}$ deposition in bottom sediment associated with industrialization and the use of leaded gasoline. In the former study, lead concentrations in the bottom sediment of Lake Washington (Seattle, WA) increased from a baseline of about $25 \mathrm{mg} \mathrm{kg}^{-1}$ to $400 \mathrm{mg} \mathrm{kg}^{-1}(1500 \%$ increase). Callender and Van Metre (1997) found an increase, and subsequent decrease, in $\mathrm{Pb}$ deposition for several reservoirs that reflect the history of leaded gasoline use in the USA. In the Callender and Van Metre study, the most pronounced $\mathrm{Pb}$ trends and largest peak concentrations were measured for the reservoirs located in urban and suburban settings. Specifically, they documented an increase in $\mathrm{Pb}$ concentrations from a baseline of about $18 \mathrm{mg} \mathrm{kg}^{-1}$ to $90 \mathrm{mg} \mathrm{kg}^{-1}$ ( $400 \%$ increase) for White Rock Lake (Dallas, TX) and an increase from a baseline of about $40 \mathrm{mg} \mathrm{kg}^{-1}$ to $150 \mathrm{mg} \mathrm{kg}^{-1}(275 \%$ increase) for Lake Harding (Atlanta, GA). In a study of seven Connecticut lakes, Siver and Wozniak (2001) found that $\mathrm{Pb}$ concentrations increased from a mean 


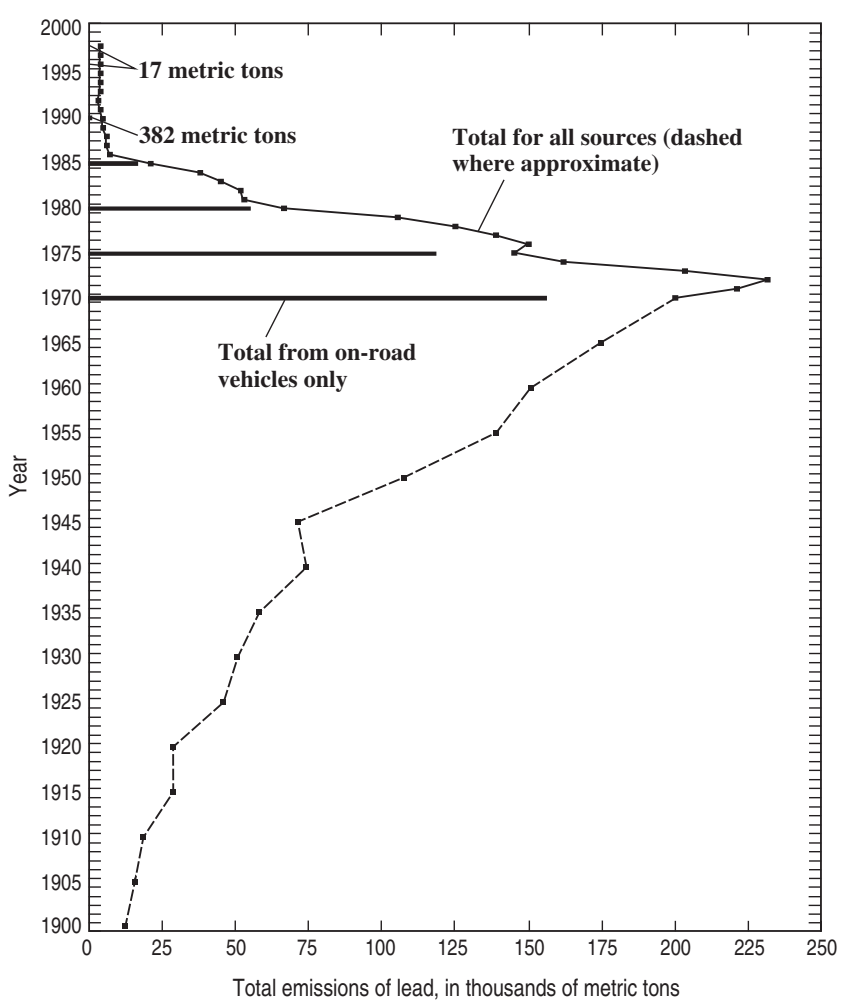

Fig. 1. Total national Pb emissions from all sources from 1900 through 1998 for the United States. Data for 1970 through 1998 from USEPA (2000). Pre-1970 emissions estimated using information for the upper Midwest from Callender and Van Metre (1997).

baseline of $31 \mathrm{mg} \mathrm{kg}^{-1}$ to a mean maximum of $310 \mathrm{mg}$ $\mathrm{kg}^{-1}$ (900\% increase).

A determination of the effects of historical leaded gasoline use on $\mathrm{Pb}$ concentrations in reservoir bottom sediment is important for several reasons. The $\mathrm{Pb}$ in the sediment may affect sediment-dwelling organisms, and it also may enter the food chain and bioaccumulate (Wong et al., 1978; Jaworski, 1987; Wright and Welbourn, 2002). Thus, such information is fundamental for understanding the effects of vehicle emissions on habitat quality. Second, an understanding of the magnitude of $\mathrm{Pb}$ concentrations in bottom sediment is important for future reservoir management. For example, decisions to draw down or dredge a reservoir may include consideration of the potential remobilization of sediment-associated contaminants such as $\mathrm{Pb}$ and the possible environmental consequences. Also, dam removal or failure may result in the introduction of large quantities of $\mathrm{Pb}$-contaminated sediment to the downstream environment. Doyle et al. (2003), citing Shuman (1995), noted that the increased recent interest in dam removal as a management option has exposed a lack of fundamental information on the physical, chemical, or biological effects of removing dams. A component of the needed information is an understanding of the quality of the impounded sediment before it is released downstream. Third, there is the question of persistence. Specifically, how long will $\mathrm{Pb}$ from historical vehicle emissions continue to elevate $\mathrm{Pb}$ concentrations in sediment above baseline (i.e., pre-1920s) levels? Finally, an understanding of changes in sediment contaminant concentrations over time has implications for the estimation of contaminant loads and yields that are used in the development of total maximum daily loads.

In the study described in this paper, the goal was to investigate the effect of highway traffic on $\mathrm{Pb}$ concentrations in the bottom sediment of eight small reservoirs with predominantly rural basins in eastern Kansas, USA. Reservoirs with rural basins were selected to determine the effect of highway traffic in the absence of other sources of $\mathrm{Pb}$ often associated with urban areas (e.g., industry, powerplants). The authors were unaware of any previous study that attempted to isolate the effect of historical vehicular $\mathrm{Pb}$ emissions on reservoir sediment quality. Specific objectives were to: (i) quantify and interpret temporal changes in $\mathrm{Pb}$ concentrations in reservoir bottom sediment relative to baseline concentrations; (ii) assess the relation between sediment $\mathrm{Pb}$ concentrations, highway traffic, and other variables; (iii) evaluate the effect of historical vehicular $\mathrm{Pb}$ emissions on sediment quality using available guidelines; and (iv) estimate the time required for $\mathrm{Pb}$ to return to baseline concentrations in newly deposited sediment.

\section{METHODS Description of Study Areas}

The eight small reservoirs included in this study are located throughout eastern Kansas (Fig. 2) and have completion dates ranging from 1879 to 1993 . The reservoir basins range in size from less than 2 to about $36 \mathrm{~km}^{2}$. Original water-storage capacities range from 0.3 to 6.9 million $\mathrm{m}^{3}$ (Table 1). Current capacities are less due to the effects of ongoing sedimentation. The reservoirs have sufficient capacity to accommodate substantial additional sediment storage. Available information indicated that none of the reservoirs have been dredged.

Physiographically, the reservoir basins can be characterized with reference to the physical divisions as defined by Fenneman (1946) and Schoewe (1949). All of the basins are located within the Central Lowland Province of the Interior Plains (Fenneman, 1946). Within the Central Lowland Province, the basins are located within three separate sections-the Dissected Till Plains, the Osage Plains, and the Arkansas River Lowlands (Schoewe, 1949) (Fig. 2).

The reservoir basins located in the Dissected Till Plains of northeast Kansas include Centralia, Gardner City, Mission, and Pony Creek Lakes (Fig. 2). The Dissected Till Plains are characterized by dissected deposits of glacial till that consist of clay, silt, sand, gravel, and boulders that overlie bedrock of primarily shale and limestone, with some sandstone (Jordan and Stamer, 1995). Slopes in the basins are typically less than 10\% (USDA-SCS, 1960, 1979a, 1982b). However, in the Gardner City Lake Basin, slopes near the streams may be as much as $20 \%$ (USDA-SCS, 1979a).

Three basins are located within the Osage Plains that cover much of east-central and southeast Kansas. Within the Osage Plains, Bronson City and Crystal Lakes are located in the Osage Cuestas, whereas Otis Creek Reservoir is located in the Flint Hills Upland (Fig. 2). The Osage Cuestas generally consist of a series of irregular northeast-southwest trending escarpments between which are flat to gently rolling plains. The topography of the Flint Hills Upland is characterized as gently rolling. Throughout the Osage Plains, the underlying bedrock is primarily limestone and shale (Schoewe, 1949). Slopes in the 


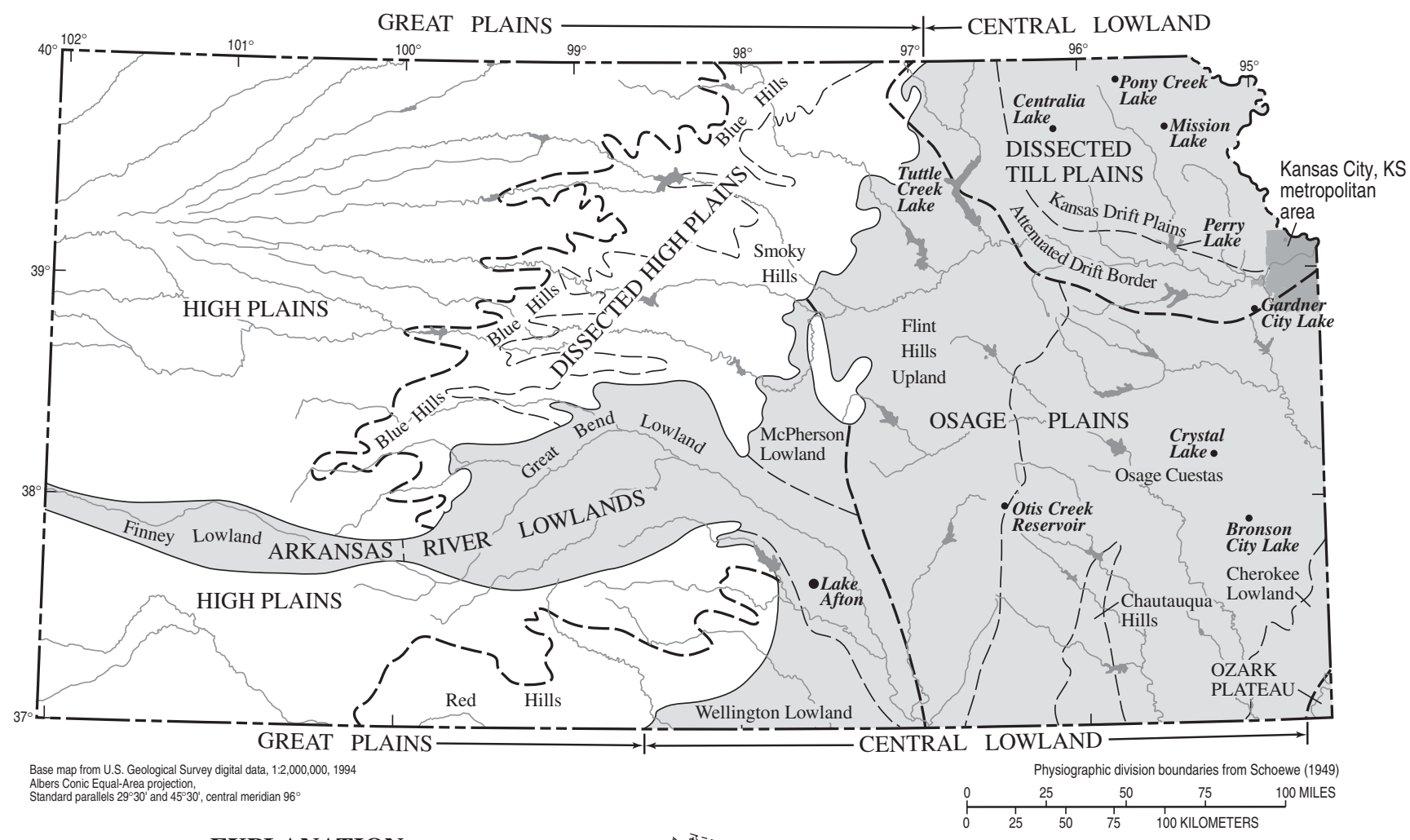

\section{EXPLANATION}

- - Boundary of major physiographic division

- - - Boundary of minor physiographic division

$\underset{\text { Afton }}{\text { Lake }} \bullet$ Reservoir included in study and reservoir name

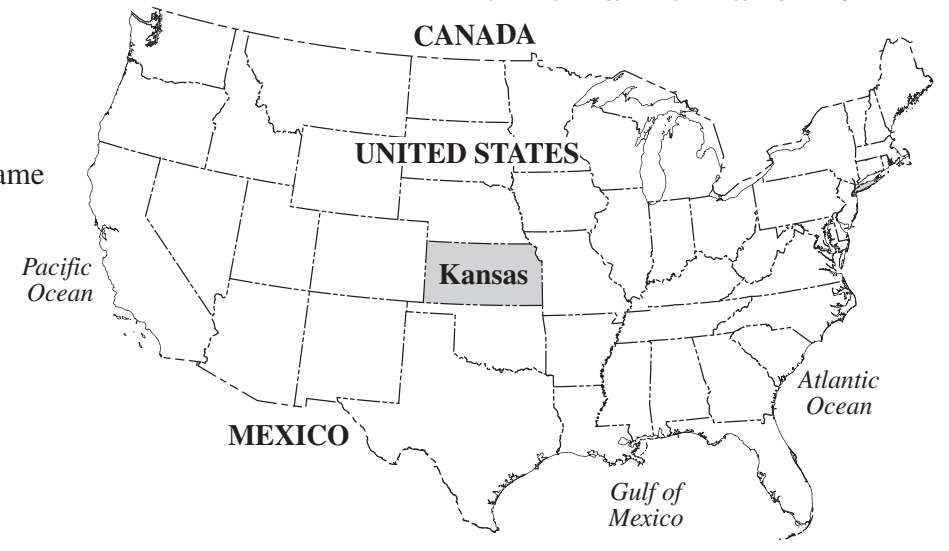

Fig. 2. Physiography of Kansas and location of small reservoirs included in study.

Bronson City and Crystal Lake Basins are generally less than 5\% (USDA-SCS, 1977, 1981). In the Otis Creek Reservoir Basin slopes are generally 5 to $20 \%$ (USDA-SCS, 1982a).

Lake Afton, in south-central Kansas, is located in the Great Bend Lowland of the Arkansas River Lowlands (Fig. 2). In this area, the topography is generally flat with little relief. Typically, slopes in the basin are $3 \%$ or less (USDA-SCS, 1979b). Surficial materials are mostly sand and gravel (Schoewe, 1949).

Long-term mean annual precipitation for Centralia, Mission, and Pony Creek Lakes is about $89 \mathrm{~cm}$. For Bronson City, Crystal, and Gardner City Lakes, the long-term mean annual precipitation is about $99 \mathrm{~cm}$. For Lake Afton and Otis Creek Reservoir, the long-term mean annual precipitation is about 76 and $84 \mathrm{~cm}$, respectively (High Plains Regional Climate Center, 2002). Most of the annual precipitation is received during the growing season (generally, April-September).

Land use (1988 through 1990) in the basins is mostly an agricultural mix of cropland and grassland (Kansas Applied Remote Sensing Program, 1993). The percentage of cropland in the basins ranges from $0.1 \%$ for Otis Creek Reservoir to $81.0 \%$ for Lake Afton. Grassland percentages range from $14.3 \%$ for Lake Afton to $96.4 \%$ for Otis Creek Reservoir. Woodland accounts for less than $7 \%$ of each basin. With two exceptions, urban land use in the basins may be considered negligible. The exceptions are the Crystal and Gardner City Lake Basins, which have 18.0 and $17.3 \%$ urban land use, respectively (Table 2). Gardner City Lake is situated on the southwestern fringe of the rapidly growing Kansas City metropolitan area. With the exceptions of Centralia Lake and Otis Creek Reservoir, every reservoir has a U.S. highway within its basin.

\section{Site Selection and Sediment Sampling}

Bottom-sediment cores were collected from each reservoir either in the fall of 2002 or the spring of 2003. With the exception of Otis Creek Reservoir, the cores were collected from a site located in the downstream one-third of the reservoir relatively close to the dam. The near-dam site was selected because it is the deepest part of each reservoir where the sediment is fine-grained and least likely to be disturbed. 
Table 1. Completion date, approximate basin size, and original waterstorage capacity for eight small reservoirs in eastern Kansas.

\begin{tabular}{|c|c|c|c|}
\hline Reservoir (Fig. 2) & $\begin{array}{c}\text { Year } \\
\text { completed }\end{array}$ & $\begin{array}{l}\text { Approximate } \\
\text { basin size }\end{array}$ & $\begin{array}{l}\text { Original water- } \\
\text { storage capacity } \dagger\end{array}$ \\
\hline & & $\mathrm{km}^{2}$ & million $\mathrm{m}^{3}$ \\
\hline Bronson City Lake & 1956 & 2.1 & $-\ddagger$ \\
\hline Centralia Lake & 1990 & 32.4 & 5.9 \\
\hline Crystal Lake & 1879 & 1.6 & 0.3 \\
\hline Gardner City Lake & 1940 & 14.2 & 2.8 \\
\hline Lake Afton & 1942 & 26.9 & 4.0 \\
\hline Mission Lake & 1924 & 22.3 & 2.3 \\
\hline Otis Creek Reservoir & 1971 & 36.3 & 6.9 \\
\hline Pony Creek Lake & 1993 & 17.1 & 2.9 \\
\hline
\end{tabular}

$\dagger$ Original water-storage capacity from Juracek (2004).

$\leftarrow-$, not available or not determined.

The cores were collected in water depths that ranged from 3.4 to $10.7 \mathrm{~m}$. With the exception of Otis Creek Reservoir, the cores were collected using a Benthos gravity corer mounted on a pontoon boat. The liner used in the gravity corer was cellulose acetate butyrate transparent tubing (with a $6.67-\mathrm{cm}$ i.d.). At Otis Creek Reservoir, because of restricted boat access and relatively thin sediment deposits, sediment samples were collected from the middle of the reservoir using a Wildco box corer. The inside dimensions of the transparent plastic liner used in the box corer were $14 \mathrm{~cm}$ long by $14 \mathrm{~cm}$ wide by $20.3 \mathrm{~cm}$ deep. Overall, the collected cores ranged in length from 0.2 to $2.4 \mathrm{~m}$.

Sediment samples for Otis Creek Reservoir were removed onsite directly from the box corer, placed in sample jars, and homogenized using a plastic stirring rod. The sediment cores collected from the other reservoirs were refrigerated (at 4 to $5^{\circ} \mathrm{C}$ ) and processed within $1 \mathrm{wk}$ after collection at the U.S. Geological Survey (USGS) laboratory in Lawrence, KS. The core liners were cut lengthwise in two places $180^{\circ}$ apart. The cuts were completed with a $10.2-\mathrm{cm}$ hand-held circular saw with its blade set at a depth to minimize penetration of the sediment cores. The cores were split in half by pulling a tightly held nylon string through the length of the cores and allowing the halves to separate. Once split, the relatively undisturbed inner parts of the cores were exposed for examination and sampling. On the basis of differences in moisture content, texture, and organic matter content (e.g., root hairs, sticks, leaves), the boundary between the bottom sediment and the underlying original (pre-reservoir) land-surface (or channel-bed) material was determined. Typically, the bottom sediment was characterized by higher moisture content, finer texture, and little if any visible organic matter as compared to the original material.

For each reservoir, the number of core intervals sampled was dependent on the age of the reservoir, the length of the core, and the amount of material required for analyses. From each interval, a representative volume of sediment was removed with care taken to avoid the sediment that came into contact with the core liner and the saw blade. The removed material was homogenized and sampled for subsequent analyses.

Age dating of the sediment samples, using cesium-137 $\left({ }^{137} \mathrm{Cs}\right)$, was performed for Crystal Lake, Gardner City Lake, Lake Afton, and Mission Lake. Age dating served the dual purpose of verifying that the bottom sediment was relatively undisturbed if the 1963 to $1964{ }^{137} \mathrm{Cs}$ peak was well-defined and followed by a generally uniform, exponential decrease in activity to the top of the core. For Crystal Lake, 15 intervals were analyzed for age-dating purposes, whereas 10 intervals were analyzed for each of the other three reservoirs. Due to an insufficient amount of material, age dating of the sediment was not performed for Bronson City Lake. Age dating was not performed for the sediment in Centralia Lake, Otis Creek Reservoir, and Pony Creek Lake because the reservoirs were too young for a meaningful analysis.

For $\mathrm{Pb}$ analyses, the objective was to analyze enough samples within each core to enable the determination of a representative median concentration as well as an indication of temporal trends. For Bronson City Lake, limited core length dictated that three intervals were sampled for analyses. For Centralia and Pony Creek Lakes, three intervals were appropriate given the young age of the reservoirs. Five intervals were sampled for Gardner City Lake, Lake Afton, Mission Lake, and Otis Creek Reservoir. For Crystal Lake, the core was of sufficient length to accommodate 10 intervals, which was justified given the older age of the reservoir. Also, for Lake Afton, a second core was sampled for 10 intervals to enable a comparison with the five-interval core to assess the effects of averaging on $\mathrm{Pb}$ concentrations. All sediment samples used for $\mathrm{Pb}$ determinations were subjected to a particlesize analysis that used standard methods (Guy, 1969; Grosbois et al., 2001).

\section{Laboratory Analysis}

For age-dating purposes, the bottom-sediment samples were analyzed for ${ }^{137} \mathrm{Cs}$ activity. Analyses were performed at the USGS National Water-Quality Laboratory in Denver, Colorado. The samples were dried and pulverized with a mortar and pestle to achieve a homogenous sample matrix. Activities of ${ }^{137} \mathrm{Cs}$ were measured by counting the samples in a calibrated geometry by gamma-ray spectrometry using a germanium detector (ASTM, 2003).

The bottom-sediment samples were analyzed for $\mathrm{Pb}$ content as bulk samples. Analyses were performed at the USGS Sediment Trace Element Partitioning Laboratory in Atlanta, Georgia. The samples were oven dried at $105^{\circ} \mathrm{C}$. For each sample, a 500-mg aliquot was digested with a combination of $\mathrm{HF} / \mathrm{HClO}_{4} /$ aqua regia in Teflon beakers at $200^{\circ} \mathrm{C}$. The resulting salts were solubilized using $50 \mathrm{~mL}$ of $2 \% \mathrm{HCl}$. The $\mathrm{Pb}$ concentration was determined by flame atomic absorption spectrometry using mixed salt standards and background correction.

Table 2. Land-use percentages for eight small reservoir basins in eastern Kansas. Land-use data from Kansas Applied Remote Sensing Program (1993).

\begin{tabular}{|c|c|c|c|c|c|c|}
\hline \multirow[b]{2}{*}{ Reservoir (Fig. 2) } & \multicolumn{6}{|c|}{ Land use ( $\%$ of basin) } \\
\hline & Cropland & Grassland & Woodland & Urban & Water & Other \\
\hline Bronson City Lake & 61.0 & 29.5 & 6.5 & $\mathbf{0}$ & 3.0 & $\mathbf{0}$ \\
\hline Centralia Lake & 77.1 & 17.6 & 2.1 & 0 & 3.0 & 0.1 \\
\hline Crystal Lake & 10.7 & 65.3 & 0.7 & 18.0 & 5.3 & 0 \\
\hline Gardner City Lake & 30.8 & 43.0 & 3.4 & 17.3 & 4.3 & 1.1 \\
\hline Lake Afton & 81.0 & 14.3 & 0.9 & 0 & 3.5 & 0.3 \\
\hline Mission Lake & 69.9 & 25.0 & 1.4 & 0.5 & 3.1 & 0.1 \\
\hline Otis Creek Reservoir & 0.1 & 96.4 & 0.1 & $\mathbf{0}$ & 3.4 & 0 \\
\hline Pony Creek Lake & 52.8 & 32.8 & 3.5 & 5.6 & 5.2 & 0.1 \\
\hline
\end{tabular}


The detection limit was $1.0 \mathrm{mg} \mathrm{kg}{ }^{-1}$. For quality assurance, precision was monitored by the replicate analyses of selected samples and by the concomitant digestion and analysis of standard soil reference samples available from USGS and the National Institute of Standards and Technology (Horowitz et al., 1989, 2001). In this study, six split-replicate samples (representing six different reservoirs) were analyzed. Analytical variability was $\pm 6 \%$. For the reference soil samples, the precision typically was within $\pm 10 \%$ of the most probable value.

\section{Statistical Analysis}

To identify the most important variables for explaining the differences in median $\mathrm{Pb}$ concentrations among reservoirs, nonparametric Spearman's rho correlation coefficients (with a significance level of 0.05) were computed (Helsel and Hirsch, 1992). The explanatory variables considered included the following: reservoir age, basin size, total length of U.S. highway in basin, shortest distance from highway to reservoir, highway density in basin, average traffic volume, product of highway density and average traffic volume, and percentage of urban land use in basin (Tables 1, 2, and 3).

Analysis of $\mathrm{Pb}$ concentrations in relation to traffic volume was constrained by the availability of information. The Kansas Department of Transportation (KDOT) provides comprehensive data on annual average daily traffic counts for all major highways and many secondary roads in Kansas. However, complete information for all of the secondary roads in the reservoir basins was not available. Thus, for the purposes of this study, the analysis focused on the presence of major highways in each basin and the attendant traffic-volume data from KDOT. The means of annual average daily traffic counts for the years 1956, 1962, 1967, 1972, 1977, and 1982 were computed to provide representative information on traffic volume within the basins for most of the period of maximum $\mathrm{Pb}$ emissions from vehicles (i.e., 1940s through the early 1980s). It was assumed that the available information, although not complete, was nevertheless sufficient to enable comparisons among the reservoirs.

\section{RESULTS AND DISCUSSION}

To assess historical changes in the $\mathrm{Pb}$ concentrations of the reservoir bottom sediment, a baseline (i.e., pre1920s) was established for the purpose of comparison. An accepted approach for determining the enrichment of recent sediment is comparison to a shale standard.
Forstner and Wittmann (1981), citing Turekian and Wedepohl (1961), stated that the average $\mathrm{Pb}$ content in shale is $20 \mathrm{mg} \mathrm{kg}^{-1}$. Davies (1990) reported an average $\mathrm{Pb}$ content of $23 \mathrm{mg} \mathrm{kg}^{-1}$ for shale.

In addition to values reported in the literature, $\mathrm{Pb}$ concentrations in sediment cores for selected reservoirs also were considered for baseline. Of the eight reservoirs included in this study, Otis Creek Reservoir was least affected by human activity. Its basin is almost exclusively grassland (Table 2) and includes no highways. Bottom sediment concentrations of $\mathrm{Pb}$ were very consistent over time (Table 4 ), and the minimal variability (within $\pm 5 \%$ of the median value) may be due, in part, to analytical variance. For Otis Creek Reservoir, the median concentration of $\mathrm{Pb}$ in the bottom sediment was $23 \mathrm{mg} \mathrm{kg}^{-1}$. Rice (1999) found streambed-sediment samples collected in two predominantly rural areas to have trace-element concentrations (including $\mathrm{Pb}$ ) similar to the local baseline (i.e., minimally affected by human activity).

If a reservoir is sufficiently old and the bottom sediment has not been disturbed, the deepest (oldest) sediment may provide an indication of baseline conditions. Completed in 1879, Crystal Lake satisfies these criteria. The profile of ${ }^{137} \mathrm{Cs}$ activity (i.e., well-defined peak followed by a uniform, exponential decline) confirmed that the sediment in Crystal Lake has not been disturbed (Fig. 3A). The deepest two intervals (1 and 2) of the core collected from Crystal Lake, interpreted to be representative of sediment deposited mostly during the late 1800 s (i.e., well before the advent of leaded gasoline), had an average $\mathrm{Pb}$ concentration of $30 \mathrm{mg} \mathrm{kg}^{-1}$ (Fig. 3A). Thus, when compared to Otis Creek Reservoir, regional differences in baseline $\mathrm{Pb}$ concentrations were apparent. Variability in baseline $\mathrm{Pb}$ concentrations also has been documented elsewhere. For example, in a study of seven Connecticut lakes, Siver and Wozniak (2001) reported a range in baseline $\mathrm{Pb}$ concentrations of 12 to $54 \mathrm{mg} \mathrm{kg}^{-1}$ with a mean of $31 \mathrm{mg} \mathrm{kg}^{-1}$. To enable an assessment of changes in $\mathrm{Pb}$ deposition in and among the eight reservoirs, the $\mathrm{Pb}$ baseline concentration for this study was set at $30 \mathrm{mg} \mathrm{kg}^{-1}$. Reservoirs with bottom-sediment concentrations less than the baseline were considered to be minimally affected by human sources of $\mathrm{Pb}$.

Table 3. Median Pb concentrations in bottom sediment, total U.S. highway length in each reservoir basin, shortest distance from highway to reservoir, highway density in each basin, average daily traffic volume, and product of highway density and average traffic volume. All values rounded to two or three significant digits.

\begin{tabular}{|c|c|c|c|c|c|c|}
\hline Reservoir (Fig. 2) & $\begin{array}{c}\text { Median Pb } \\
\text { concentration in } \\
\text { bottom sediment }\end{array}$ & $\begin{array}{l}\text { Total length of } \\
\text { U.S. highway } \\
\text { in basin }\end{array}$ & $\begin{array}{c}\text { Shortest distance } \\
\text { from highway } \\
\text { to reservoir }\end{array}$ & $\begin{array}{c}\text { Highway density } \\
\text { in basin } \dagger\end{array}$ & $\begin{array}{c}\text { 1956-82 Average daily } \\
\text { traffic volume } \\
\text { (number of vehicles) } \$\end{array}$ & $\begin{array}{c}\text { Product of highway } \\
\text { density and average } \\
\text { traffic volume }\end{array}$ \\
\hline & $\mathrm{mg} \mathrm{kg}^{-1}$ & 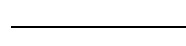 & $\mathbf{m}$ & $\mathrm{km} \mathrm{km}^{-2}$ & & \\
\hline Bronson City Lake & 34 & 1.8 & 0.2 & 0.9 & 1660 & 1490 \\
\hline Centralia Lake & 19 & 0 & $-\mathrm{II}$ & 0 & o & 0 \\
\hline Crystal Lake & $59 \S$ & 1.2 & $<0.03$ & 0.8 & 2710 & 2170 \\
\hline Gardner City Lake & 42 & 1.9 & 2.8 & 0.1 & 4660 & 466 \\
\hline Lake Afton & 45 & 4.0 & 4.6 & 0.1 & 4550 & 455 \\
\hline Mission Lake & 29 & 4.7 & 0.4 & 0.2 & 1670 & 334 \\
\hline Otis Creek Reservoir & 23 & $\mathbf{0}$ & - & $\mathbf{0}$ & $\mathbf{0}$ & $\mathbf{0}$ \\
\hline Pony Creek Lake & 25 & 5.2 & 0.2 & 0.3 & 1530 & 459 \\
\hline
\end{tabular}

$\dagger$ Highway density computed as total highway length divided by basin area.

$\$$ Data from the Kansas Department of Transportation (personal communication, 2003).

$\S$ Computed using the top (most recent) seven core intervals only.

II - , not determined. 
Table 4. Concentration of $\mathrm{Pb}$ in bottom sediment of eight small reservoirs in eastern Kansas. Completion date for each reservoir is indicated parenthetically.

\begin{tabular}{|c|c|c|c|c|c|c|c|c|c|}
\hline \multirow[b]{2}{*}{$\begin{array}{l}\text { Sediment-core } \\
\text { interval }\end{array}$} & \multicolumn{9}{|c|}{$\mathbf{P b}$ concentration $\dagger$} \\
\hline & $\begin{array}{l}\text { Bronson City } \\
\text { Lake }(1956) \div\end{array}$ & $\begin{array}{c}\text { Centralia } \\
\text { Lake (1990) }\end{array}$ & $\begin{array}{c}\text { Crystal Lake } \\
(1879) \ddagger\end{array}$ & $\begin{array}{l}\text { Gardner City } \\
\text { Lake (1940) } \uparrow\end{array}$ & $\begin{array}{r}\text { Lake } \\
\text { (1S }\end{array}$ & $\begin{array}{l}\text { Afton } \\
2) \div\end{array}$ & $\begin{array}{c}\text { Mission Lake } \\
\text { (1924) } †\end{array}$ & $\begin{array}{c}\text { Otis Creek } \\
\text { Reservoir (1971) }\end{array}$ & $\begin{array}{l}\text { Pony Creek } \\
\text { Lake (1993) }\end{array}$ \\
\hline & & & & 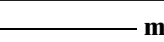 & $\mathrm{kg}^{-1}$ & & & & \\
\hline \multirow[t]{9}{*}{ Top (most recent) } & 32 & 19 & $51 *$ & $40 *$ & $39 *$ & 34 & 29 & 23 & 25 \\
\hline & 34 & 19 & $59 *$ & $50 *$ & $53 *$ & 35 & 30 & 23 & 24 \\
\hline & $38 *$ & 17 & $65 *$ & $49 *$ & $54 *$ & $43 *$ & 31 & 23 & 25 \\
\hline & - & - & $62 *$ & $42 *$ & $45 *$ & $55 *$ & 24 & 23 & - \\
\hline & - & - & $64 *$ & $39 *$ & 34 & $55 *$ & 25 & 24 & - \\
\hline & - & - & $46 *$ & - & - & $50 *$ & - & - & - \\
\hline & - & - & $36 *$ & - & - & $43 *$ & - & - & - \\
\hline & - & - & 31 & - & - & $36 *$ & - & - & - \\
\hline & - & - & 32 & - & - & 31 & - & - & - \\
\hline Bottom (oldest) & - & - & 28 & - & - & 28 & - & - & - \\
\hline
\end{tabular}

$\dagger$ Concentrations in italic exceed the USEPA (1997) threshold-effects level (TEL) (30.2 $\mathrm{mg} \mathrm{kg}^{-1}$ ) for possible adverse biological effects. Concentrations marked with an asterisk (*) exceed the MacDonald et al. (2000) consensus-based threshold-effects concentration (TEC) (35.8 mg kg ${ }^{-1}$ ) for possible adverse biological effects.

$\$$ Lead depositional profile reflects history of leaded gasoline use.

\section{Lead Depositional Histories}

Of the eight reservoirs sampled, five (Bronson City Lake, Crystal Lake, Gardner City Lake, Lake Afton, and Mission Lake) had a $\mathrm{Pb}$ depositional profile in the sediment core that reflected the history of leaded gasoline use (Table 4). The best example is provided by the relatively detailed core analyzed for Crystal Lake (Fig. 3A) that represents $124 \mathrm{yr}$ of sediment deposition. The bottom (oldest) part of the core, intervals 1 through 3, had baseline $\mathrm{Pb}$ concentrations. Progressing forward in time, $\mathrm{Pb}$ concentrations increased and culminated with a peak concentration of $65 \mathrm{mg} \mathrm{kg}^{-1}$ for interval 8. A side-by-side comparison of the $\mathrm{Pb}$ and ${ }^{137} \mathrm{Cs}$ (Fig. 3A) profiles indicated that the $\mathrm{Pb}$ peak occurred in the 1970s. Subsequently, $\mathrm{Pb}$ concentrations declined to a value of $51 \mathrm{mg}$ $\mathrm{kg}^{-1}$ for the top (most recent) interval. Over the life of the reservoir, $\mathrm{Pb}$ concentrations in the bottom sediment more than doubled (117\% increase) from the initial baseline conditions before declining. From the peak, $\mathrm{Pb}$ concentrations have decreased by at least $22 \%$ to the present. Because each core interval integrates several years of deposition, the most recent sediment likely has $\mathrm{Pb}$ concentrations less than $51 \mathrm{mg} \mathrm{kg}^{-1}$. Although the elimination of leaded gasoline was essentially achieved by 1990 , the increased $\mathrm{Pb}$ concentration (relative to baseline) for interval 10 at the top of the core indicated that residual $\mathrm{Pb}$ was still being transported into the reservoir from the basin post-1990. Interval 10 includes sediment deposited up until the time of core collection in 2003.

Additional evidence in support of vehicular traffic as the source of $\mathrm{Pb}$ was provided by $\mathrm{Zn}$ concentrations in the sediment. Over the life of Crystal Lake, a statistically significant increasing trend in $\mathrm{Zn}$ deposition was indicated (Juracek, 2004). A significant source of $\mathrm{Zn}$ is vehicular tire wear. Callender and Rice (2000) determined that increased $\mathrm{Zn}$ concentrations in sediment are related to increased vehicular traffic.

A similar $\mathrm{Pb}$ depositional profile was indicated for Gardner City Lake, Lake Afton, and Mission Lake (Table 4). The $\mathrm{Pb}$ concentrations in the bottom sediment of these three reservoirs likely were affected to an unknown extent by sediment storage in multiple smaller upstream impoundments located between the highway and the reservoir in each basin. For Gardner City Lake (completed in 1940), $\mathrm{Pb}$ concentrations increased from an initial value of $39 \mathrm{mg} \mathrm{kg}^{-1}$ at the bottom of the core to a peak of $50 \mathrm{mg} \mathrm{kg}^{-1}$ ( $28 \%$ increase) before declining to $40 \mathrm{mg} \mathrm{kg}^{-1}$ (20\% decrease). The larger initial $\mathrm{Pb}$ concentration, relative to the baseline, is consistent with the age of the reservoir, which was completed after leaded gasoline had already been in use for several years. Thus, assuming that the increased $\mathrm{Pb}$ concentrations were attributable primarily to historical vehicle emissions, it is anticipated that $\mathrm{Pb}$ concentrations in newly deposited bottom sediment of Gardner City Lake eventually will stabilize at a level less than $39 \mathrm{mg} \mathrm{kg}^{-1}$.

For Lake Afton (completed in 1942), $\mathrm{Pb}$ concentrations in the five-interval core increased from an initial value of $34 \mathrm{mg} \mathrm{kg}^{-1}$ to a peak of $54 \mathrm{mg} \mathrm{kg}^{-1}$ (59\% increase) before declining to $39 \mathrm{mg} \mathrm{kg}^{-1}$ (28\% decrease). For the 10-interval core (Fig. 3B), Pb concentrations increased from an initial value of $28 \mathrm{mg} \mathrm{kg}^{-1}$ to a peak of $55 \mathrm{mg} \mathrm{kg}^{-1}$ (96\% increase) before declining to $34 \mathrm{mg} \mathrm{kg}^{-1}$ ( $38 \%$ decrease). A comparison of the five- and 10-interval cores documented the expected effect of averaging when fewer intervals are used to represent the same sediment profile. Specifically, the range in $\mathrm{Pb}$ concentrations for the 10-interval core ( 28 to $55 \mathrm{mg} \mathrm{kg}^{-1}$ ) was reduced in the five-interval core ( 34 to $54 \mathrm{mg} \mathrm{kg}^{-1}$ ) by $26 \%$. Assuming that the increased $\mathrm{Pb}$ concentrations were attributable primarily to historical vehicle emissions and given that the oldest (deepest) sediment had a $\mathrm{Pb}$ concentration of $28 \mathrm{mg} \mathrm{kg} \mathrm{g}^{-1}$, it is anticipated that $\mathrm{Pb}$ concentrations in newly deposited bottom sediment of Lake Afton eventually will stabilize at a level less than $34 \mathrm{mg} \mathrm{kg}^{-1}$.

For Mission Lake (completed in 1924), the Pb depositional profile indicated an analogous, although somewhat less pronounced, history. From an initial concentration of $25 \mathrm{mg} \mathrm{kg}^{-1}, \mathrm{~Pb}$ peaked at $31 \mathrm{mg} \mathrm{kg}^{-1}$ (24\% increase) and then declined to $29 \mathrm{mg} \mathrm{kg}^{-1}$ ( $6 \%$ decrease). The fact that all of the $\mathrm{Pb}$ concentrations were near or less than baseline $\left(30 \mathrm{mg} \mathrm{kg}^{-1}\right)$ throughout the life of the reservoir indicated that the historical use of leaded gasoline had a relatively smaller effect in this reservoir compared 


\section{A. Crystal Lake}
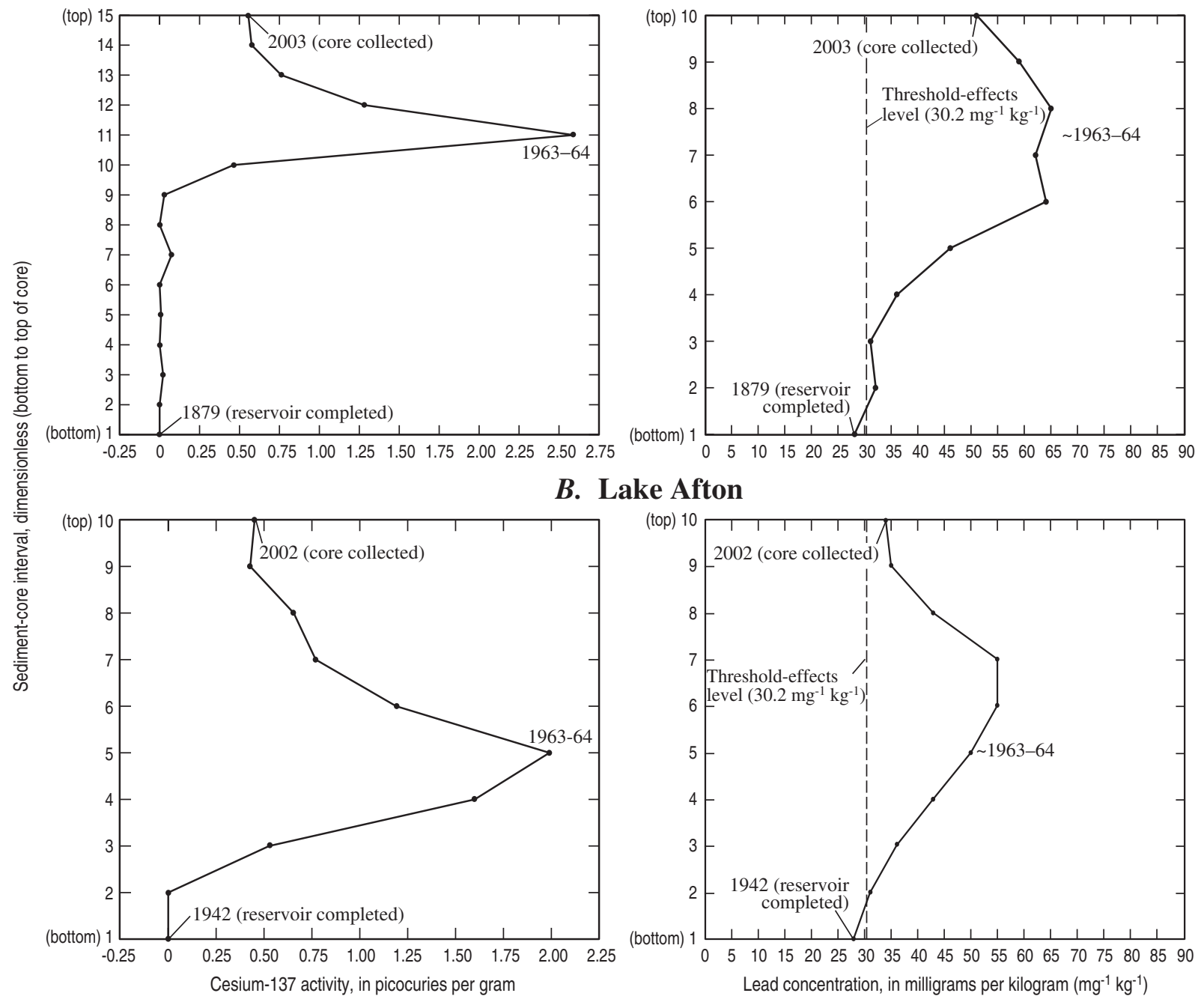

B. Lake Afton

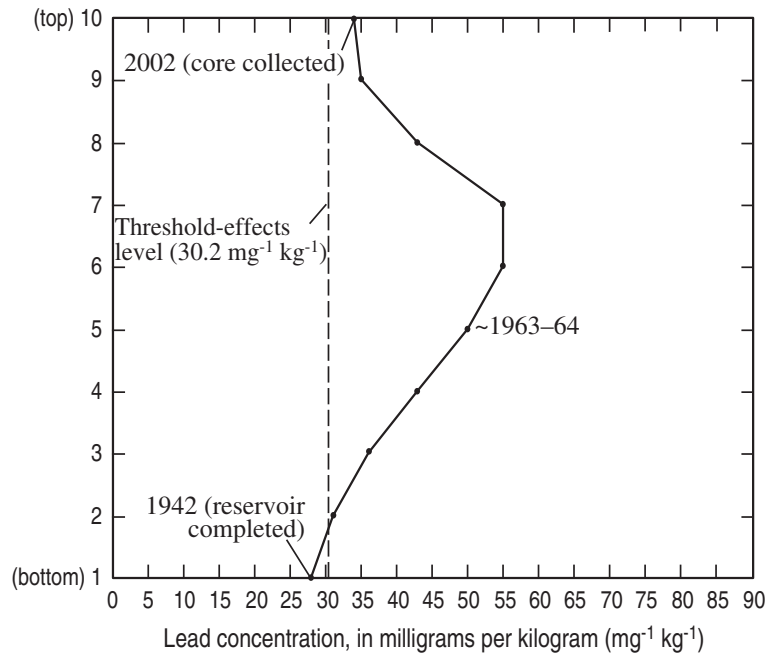

Fig. 3. Cesium-137 and Pb depositional profiles for (A) Crystal Lake and (B) Lake Afton. Sediment-quality guidelines from USEPA (1997).

to the previously discussed reservoirs. Also, given the limited range in concentrations, analytical variability may have accounted for some of the change. Because the deepest core interval corresponds to the time period that represents the first few years of leaded gasoline use, the measured $\mathrm{Pb}$ concentration probably is close to the true baseline for the basin.

The $\mathrm{Pb}$ depositional profile for Bronson City Lake (completed in 1956), although limited to three intervals, nevertheless indicated a possible decrease in $\mathrm{Pb}$ concentrations from $38 \mathrm{mg} \mathrm{kg}^{-1}$ at the bottom of the core to $32 \mathrm{mg} \mathrm{kg}^{-1}$ at the top. The decrease is consistent with the history of leaded gasoline use. Although, given the limited range in concentrations, analytical variability is another possible explanation.

For the three remaining reservoirs, historical leaded gasoline use has had a minimal effect on $\mathrm{Pb}$ concentrations in the bottom sediment. All three reservoirs had $\mathrm{Pb}$ concentrations that were uniform over time and less than baseline. Otis Creek Reservoir (completed in 1971) is located in a relatively remote area. The basin is almost exclusively grassland and includes no highways. More- over, no highways are located within several kilometers of the basin in every direction. The existence of both Centralia Lake (completed in 1990) and Pony Creek Lake (completed in 1993) postdates the period during which $\mathrm{Pb}$ emissions from vehicle exhaust were largest (i.e., 1940s through the early 1980s). Thus, the $\mathrm{Pb}$ deposited in these two basins during the period of peak emissions may have partly or mostly been transported downstream by fluvial processes before construction of the dams. Also, dilution of the $\mathrm{Pb}$ concentrations by "clean" sediment (i.e., sediment minimally contaminated by vehicle $\mathrm{Pb}$ emissions) within the basins is a likely contributing factor. In all three cases, the uniformity of the $\mathrm{Pb}$ concentrations over time (i.e., the lack of a decreasing trend) indicates that the concentrations are at or near the true baseline for each reservoir.

\section{Lead Concentrations and Explanatory Variables}

Several variables may account, in part, for the $\mathrm{Pb}$ concentrations measured in the reservoir bottom sediment. Sediment characteristics that can affect $\mathrm{Pb}$ con- 
centrations include particle size (e.g., sand content) and organic matter content (Horowitz, 1991). All sediment samples analyzed for this study (i.e., the individual core intervals) had a silt and (or) clay content of $98 \%$ or greater and a total organic carbon (TOC) content generally in the range of 2.0 to $3.5 \%$ (Juracek, 2004). Thus, particle size likely is not important for explaining differences in $\mathrm{Pb}$ concentrations within the individual reservoir sediment cores. Normalization using TOC did not substantially affect the relative magnitudes and trends of the $\mathrm{Pb}$ concentrations within the individual cores.

Statistical analysis indicated significant positive correlations between median $\mathrm{Pb}$ concentrations and average traffic volume (1956 through 1982), the product of highway density and average traffic volume, and reservoir age (Table 5). Of these three variables, average traffic volume was the best predictor of median $\mathrm{Pb}$ concentration. The strong correlation between traffic volume and median $\mathrm{Pb}$ concentrations was not surprising because the primary source of $\mathrm{Pb}$ was from vehicular emissions. The correlation between reservoir age and median $\mathrm{Pb}$ concentrations was indicative of the fact that the amount of $\mathrm{Pb}$ deposition was directly related to the amount of overlap between the existence of the reservoir and the period of maximum $\mathrm{Pb}$ emissions.

A negative correlation (significant at the 0.06 level) was indicated between median $\mathrm{Pb}$ concentration and basin size (Table 5). This relation is possibly suggestive of the importance of basin size as an indicator of the availability of "clean" sediment to dilute $\mathrm{Pb}$ concentrations in reservoir bottom sediment. Alternatively, the relation may be a result of the small sample size and (or) sediment storage in the basin.

No statistically significant correlations were indicated between median $\mathrm{Pb}$ concentrations and total length of U.S. highway in each basin, shortest distance from highway to reservoir, highway density in each basin, and percentage of urban land use in each basin (Table 5). However, for Crystal Lake, distance from highway to reservoir apparently was important. Crystal Lake had the largest median $\mathrm{Pb}$ concentration despite a traffic volume that was about $40 \%$ less than the traffic volume for the highways in the Gardner City Lake and Lake Afton Basins. The shortest distance from the highway to the shore of Crystal Lake is less than $0.03 \mathrm{~km}$, whereas the respective shortest distances for Gardner City Lake and Lake Afton are about 2.8 and $4.6 \mathrm{~km}$, respectively (Table 3). Thus, Crystal Lake may have received more

Table 5. Correlations between median Pb concentration in bottom sediment and several explanatory variables.

\begin{tabular}{lcc}
\hline Explanatory variable & Spearman's rho & $\begin{array}{c}\text { Two-sided } \\
p \text {-value }\end{array}$ \\
\hline Reservoir age & $\mathbf{0 . 7 6}$ & $\mathbf{0 . 0 2 8 0 0}$ \\
Basin size & $-\mathbf{0 . 6 9}$ & $\mathbf{0 . 0 5 7 9 9}$ \\
Total length of U.S. highway in basin & $\mathbf{0 . 2 5}$ & $\mathbf{0 . 5 4 7 9 4}$ \\
$\begin{array}{l}\text { Shortest distance from highway to } \\
\text { reservoir }\end{array}$ & $\mathbf{0 . 0 3}$ & $\mathbf{0 . 9 5 6 5 3}$ \\
Highway density in basin & 0.53 & $\mathbf{0 . 1 7 6 5 1}$ \\
Average traffic volume (1956-82) & 0.87 & $\mathbf{0 . 0 0 4 5 1}$ \\
Product of highway density and & 0.78 & $\mathbf{0 . 0 2 2 8 7}$ \\
$\quad \begin{array}{l}\text { traffic volume } \\
\text { Percentage urban land use in basin }\end{array}$ & 0.49 & $\mathbf{0 . 2 1 2 7 0}$ \\
\hline
\end{tabular}

$\mathrm{Pb}$ via direct atmospheric deposition. Also, basin size may be an important factor. In this case, the larger $\mathrm{Pb}$ concentrations in the Crystal Lake sediment may be partly because of the small basin size (relative to the other two reservoirs, see Table 1) and the associated limited potential for dilution by "clean" sediment and (or) sediment storage.

Overall, it is apparent that several factors can affect the magnitude and temporal variability of $\mathrm{Pb}$ concentrations in the bottom sediment of small rural reservoirs in eastern Kansas. Statistically significant factors (at the 0.06 level or better) included traffic volume, reservoir age, and basin size. Also, $\mathrm{Pb}$ concentrations likely are affected by a relatively substantial percentage of urban land use in the Crystal Lake and Gardner City Lake Basins (Table 2).

The presence or absence of temporal trend in $\mathrm{Pb}$ concentrations documented in this and other studies suggests that basin size may be an important determinant of $\mathrm{Pb}$ concentrations in the bottom sediment of rural reservoirs. In this study, sediment cores collected from five of eight small rural reservoirs displayed a $\mathrm{Pb}$ depositional profile that reflected the history of leaded gasoline use. The basins for these five reservoirs are less than $30 \mathrm{~km}^{2}$ in size (Table 1). However, for rural reservoirs with larger basins, the $\mathrm{Pb}$ concentrations attributable to historical leaded gasoline use may be diluted by a large contribution of "clean" sediment (Callender and Van Metre, 1997). For example, a depositional trend for $\mathrm{Pb}$ was absent in a 10interval core analyzed for Perry Lake, Kansas (completed in 1969) (Fig. 2) (Juracek, 2003). Mission Lake (for which a $\mathrm{Pb}$ depositional trend was measured) is located within the $2890-\mathrm{km}^{2}$ Perry Lake Basin. Elsewhere, a depositional trend for $\mathrm{Pb}$ was absent in a 15-interval core analyzed for Tuttle Creek Lake, Kansas (completed in 1962) (Fig. 2) (Juracek and Mau, 2002) and in a 20-interval core analyzed for Coralville Lake, Iowa (completed in 1958) (Callender and Van Metre, 1997). The respective basin sizes for Tuttle Creek and Coralville Lakes are 24900 and $8070 \mathrm{~km}^{2}$. Additional research is required to ascertain the threshold basin size at which the $\mathrm{Pb}$ contribution from vehicular emissions may be overwhelmed by "clean" sediment in a rural reservoir.

\section{Lead Concentrations and Sediment Quality}

The U.S. Environmental Protection Agency (USEPA) has adopted nonenforceable sediment-quality guidelines (SQGs) in the form of level-of-concern concentrations for several trace elements including $\mathrm{Pb}$. These level-ofconcern concentrations were derived from biologicaleffects correlations made on the basis of paired onsite and laboratory data to relate incidence of adverse biological effects in aquatic organisms to dry-weight sediment concentrations. Two such level-of-concern guidelines adopted by USEPA are referred to as the threshold-effects level (TEL) and the probable-effects level (PEL). The TEL is assumed to represent the concentration below which toxic biological effects rarely occur. In the range of concentrations between the TEL and PEL, toxic effects occasionally occur. Toxic effects usually or frequently occur at concen- 
trations greater than the PEL. For Pb, the TEL and PEL are 30.2 and $112 \mathrm{mg} \mathrm{kg}^{-1}$, respectively (USEPA, 1997).

The USEPA cautions that the TEL and PEL guidelines are intended for use as screening tools for possible hazardous levels of chemicals and are not regulatory criteria. This cautionary statement is made because, although biological-effects correlation identifies level-ofconcern concentrations associated with the likelihood of adverse organism response, the procedure may not demonstrate that a particular chemical is solely responsible. In fact, biological-effects correlations may not indicate direct cause-and-effect relationships because coring sites may contain a mixture of chemicals that contribute to the adverse effects to some degree. Thus, for any given site, the guidelines may be over- or underprotective (USEPA, 1997). Nevertheless, the guidelines provide a means for assessing the potential toxicity of $\mathrm{Pb}$ concentrations in bottom sediment and for comparing reservoirs.

In this study, $\mathrm{Pb}$ concentrations that exceeded the TEL (30.2 mg kg-1) were measured only in sediment from the five reservoirs that had $\mathrm{Pb}$ depositional profiles that were indicative of the effect of historical leaded gasoline use. These five reservoirs were all completed before or during the period of maximum $\mathrm{Pb}$ emissions from vehicles (i.e., the 1940s through the early 1980s). The $\mathrm{Pb}$ concentrations exceeded the TEL for all intervals of the sediment core analyzed for Bronson City and Gardner City Lakes. For Crystal Lake and Lake Afton, $\mathrm{Pb}$ concentrations exceeded the TEL for all but the deepest (oldest) interval. For Mission Lake, only the peak $\mathrm{Pb}$ concentration exceeded the TEL. No measured $\mathrm{Pb}$ concentrations exceeded the PEL (112 mg kg$\left.{ }^{-1}\right)$ (Table 4).

For $\mathrm{Pb}$ (Table 4), as well as $\mathrm{As}, \mathrm{Cr}, \mathrm{Cu}, \mathrm{Ni}$, and $\mathrm{Zn}$ (Juracek, 2004), the sediment concentrations at the bottom of the Crystal Lake core were either similar to, or substantially larger than, the respective TELs (USEPA, 1997). Because the bottom of the Crystal Lake core likely is representative of baseline conditions, the results indicated that, for certain trace elements in certain areas, baseline concentrations may equal or exceed the TELs before the effects of substantial human activity.

MacDonald et al. (2000) developed consensus-based SQGs that were computed as the geometric mean of several previously published SQGs. The consensusbased SQGs consist of a threshold-effects concentration (TEC) and a probable-effects concentration (PEC). The TEC represents the concentration below which adverse biological effects are not expected to occur, whereas the PEC represents the concentration above which adverse biological effects are expected to occur more often than not. An evaluation of the reliability of the SQGs indicated that most of the individual TECs and PECs (including those for $\mathrm{Pb}$ ) provide an accurate basis for predicting the presence or absence of sediment toxicity. For $\mathrm{Pb}$, the TEC and PEC are 35.8 and $128 \mathrm{mg} \mathrm{kg}^{-1}$, respectively (MacDonald et al., 2000). In the present study, $\mathrm{Pb}$ concentrations that exceeded the TEC were measured for four of the five reservoirs that had $\mathrm{Pb}$ depositional profiles indicative of the effect of historical leaded gasoline use. No measured $\mathrm{Pb}$ concentrations exceeded the PEC (Table 4).

\section{Estimated Recovery Time}

The relatively detailed information available for Crystal Lake and Lake Afton was used to estimate the time required for newly deposited sediment to achieve baseline $\mathrm{Pb}$ concentrations (i.e., $30 \mathrm{mg} \mathrm{kg}^{-1}$ ). These projections required the following assumptions: (i) a uniform sedimentation rate over time; (ii) minimal postdepositional disturbance; (iii) an exponential rate of decline of $\mathrm{Pb}$ concentrations; and (iv) no new sources contribute to the deposition of $\mathrm{Pb}$ in the reservoirs. The location of the peak in the ${ }^{137}$ Cs profile (Fig. 3A) supports the assumption of a uniform sedimentation rate for Crystal Lake. Likewise, the ${ }^{137}$ Cs profile for Lake Afton (Fig. 3B) generally was indicative of uniform sedimentation.

For both reservoirs, a first-order rate model was fit to the $\mathrm{Pb}$ concentrations vs. time in years (Van Metre et al., 1998). The model is expressed as $C_{\mathrm{t}}=C_{\mathrm{o}} e^{-k t}$, where $C_{\mathrm{t}}$ is the $\mathrm{Pb}$ concentration at time $\mathrm{t}, C_{\mathrm{o}}$ is the initial $\mathrm{Pb}$ concentration, $k$ is the time constant, and $t$ is time in years. Because each core interval represents several years of deposition, the midpoint date was assigned to each interval for the purpose of estimating the time required for $\mathrm{Pb}$ concentrations to return to baseline. For Crystal Lake and Lake Afton, each core interval represented about 12 and $6 \mathrm{yr}$ of deposition, respectively.

For Crystal Lake, it was projected that newly deposited sediment will contain baseline $\mathrm{Pb}$ concentrations in about the year 2050 . Thus, the total recovery time for $\mathrm{Pb}$ concentrations to return to baseline following the phase out of leaded gasoline (circa 1980) was estimated to be at least $70 \mathrm{yr}$.

Lake Afton was completed after the introduction of leaded gasoline and, therefore, the baseline $\mathrm{Pb}$ concentration was not known with certainty. However, because the $\mathrm{Pb}$ concentrations in the bottom (oldest) two core intervals are relatively uniform (similar to the bottom three intervals of the Crystal Lake core), it was decided that an assumed baseline of $30 \mathrm{mg} \mathrm{kg}^{-1}$ was reasonable for use in the estimation of recovery time. For Lake Afton, it was projected that newly deposited sediment contained baseline concentrations of $\mathrm{Pb}$ in about the year 2000. Thus, the total recovery time for $\mathrm{Pb}$ concentrations to return to baseline following the phase out of leaded gasoline was estimated to be at least $20 \mathrm{yr}$. Given that the true baseline for Lake Afton may be smaller than the $30 \mathrm{mg} \mathrm{kg}^{-1}$ assumed, the actual recovery time may be longer. Moreover, additional complicating factors (e.g., implementation of best management practices, sediment releases associated with the failure or removal of small upstream impoundments) may lengthen the recovery time further.

An understanding of recovery time has important management implications. In this study it was estimated that a recovery time of at least 20 to $70 \mathrm{yr}$ was required for $\mathrm{Pb}$ concentrations in the bottom sediment of two small rural reservoirs to return to baseline following the phase out of leaded gasoline. Although based on limited data, the es- 
timated recovery time is consistent with the decadal response time of riverine systems to changes in the regulation of persistent, sediment-associated contaminants as proposed by Van Metre et al. (1998). The lengthy recovery period is a result of several factors including the amount of $\mathrm{Pb}$ originally introduced to the basin, the distance from source (highway) to sink (reservoir), the time required for sediment transport (including sediment storage) from source to sink, and the availability of "clean" sediment within the basin. Results of this study indicate that attempts to restore sediment quality in small rural reservoirs to baseline conditions by the elimination of the source of persistent, sediment-associated contaminants may not achieve the desired improvement for at least several decades.

\section{CONCLUSIONS}

In what possibly represents the first such effort, this study attempted to isolate the effect of historical vehicular $\mathrm{Pb}$ emissions on reservoir sediment quality. For the small rural reservoirs that were completed before or during the period of maximum $\mathrm{Pb}$ emissions from vehicles (the 1940s through the early 1980s) and had a major highway in the basin, $\mathrm{Pb}$ concentrations in the bottom sediment reflected the historical use of leaded gasoline. That is, $\mathrm{Pb}$ concentrations increased substantially above baseline (pre$1920 \mathrm{~s})$ concentrations $\left(30 \mathrm{mg} \mathrm{kg}^{-1}\right)$ and also exceeded the threshold-effects level (TEL) (30.2 $\mathrm{mg} \mathrm{kg}^{-1}$ ) for possible adverse biological effects. Likewise, the increased $\mathrm{Pb}$ concentrations typically also exceeded the consensus-based threshold-effects concentration (TEC) $\left(35.8 \mathrm{mg} \mathrm{kg}^{-1}\right)$ for possible adverse biological effects. Subsequently, with the phase out of leaded gasoline, $\mathrm{Pb}$ concentrations have declined but still remain above baseline and above the TEL and TEC for some of the affected reservoirs. For at least some of these reservoirs, residual $\mathrm{Pb}$ is still being delivered from the basins.

For the small rural reservoirs completed after the period of maximum $\mathrm{Pb}$ emissions and (or) located in relatively remote areas with little or no highway traffic, there was no evidence of increased $\mathrm{Pb}$ deposition in the bottom sediment. In the former case, it is proposed that the highway-derived $\mathrm{Pb}$ deposited in the basin was partly or mostly transported downstream before construction of the dams. Also, the $\mathrm{Pb}$ concentrations may have been diluted by "clean" sediment within the basins.

The results of this study indicated that several factors may affect the magnitude and variability of $\mathrm{Pb}$ concentrations in the bottom sediment of small rural reservoirs including traffic volume, reservoir age, and basin size. A relation between $\mathrm{Pb}$ concentrations and total length of highway in basin, shortest distance from highway to reservoir, highway density in basin, and percentage of urban land use in basin was not indicated.

In sum, the legacy of leaded gasoline in the bottom sediment of the affected small rural reservoirs is one of increased $\mathrm{Pb}$ concentrations and ongoing recovery. The bottom sediment containing the largest $\mathrm{Pb}$ concentrations is now capped by overlying sediment with progressively smaller $\mathrm{Pb}$ concentrations. Eventually, given enough time (i.e., at least several decades following the phase out of leaded gasoline) and assuming no new sources of $\mathrm{Pb}$, it is anticipated that $\mathrm{Pb}$ in the newly deposited sediment will return to baseline concentrations. However, the buried sediment with increased $\mathrm{Pb}$ concentrations may pose a future environmental concern if the reservoirs are dredged, the dams are removed, or the dams fail.

\section{ACKNOWLEDGMENTS}

This study was made possible in part by support from the Kansas State Water Plan Fund, the Kansas Department of Health and Environment, the U.S. Environmental Protection Agency, the U.S. Department of Agriculture's Natural Resources Conservation Service, and the Fall River Watershed Joint District No. 21 (Eureka, KS). Any use of trade, product, or firm names is for descriptive purposes only and does not constitute endorsement by the U.S. Geological Survey.

\section{REFERENCES}

Adriano, D.C. 2001. Trace elements in terrestrial environments. 2nd ed. Springer, New York.

Alexander, R.B., and R.A. Smith. 1988. Trends in lead concentrations in major U.S. rivers and their relation to historical changes in gasoline-lead consumption. Water Resour. Bull. 24:557-569.

ASTM. 2003. Standard practice for high-resolution gamma-ray spectrometry of water. p. 307-317. In Annual book of ASTM standards, Section 11, Water and environmental technology. V. 11.02, D 3649-98a. ASTM, West Conshohocken, PA.

Barrie, L.A., D. Gregor, B. Hargrave, R. Lake, D. Muir, R. Shearer, B. Tracey, and T. Bidleman. 1992. Arctic contaminants-sources, occurrence and pathways. Sci. Total Environ. 122:1-74.

Baudo, R., J.P. Giesy, and H. Muntau (ed.) 1990. Sediments-Chemistry and toxicity of in-place pollutants. Lewis Publishers, Ann Arbor, MI

Bertine, K.K., and M.F. Mendeck. 1978. Industrialization of New Haven, Conn., as recorded in reservoir sediments. Environ. Sci. Technol. 12:201-207.

Boutron, C.F., U. Gorlach, J.P. Candelone, M.A. Bolshov, and R.J. Delmas. 1991. Decrease in anthropogenic lead, cadmium, and zinc in Greenland snows since the late 1960s. Nature 353:153-156.

Callender, E., and K.C. Rice. 2000. The urban environmental gradient: Anthropogenic influences on the spatial and temporal distributions of lead and zinc in sediments. Environ. Sci. Technol. 34:232-238.

Callender, E., and P.C. Van Metre. 1997. Reservoir sediment cores show U.S. lead declines. Environ. Sci. Technol. 31:424A-428A.

Cannon, H.L., and J.M. Bowles. 1962. Contamination of vegetation by tetraethyl lead. Science 137:765-766.

Crecelius, E.A., and D.Z. Piper. 1973. Particulate lead contamination recorded in sedimentary cores from Lake Washington, Seattle. Environ. Sci. Technol. 7:1053-1055.

Daines, R.H., H. Motto, and D.M. Chilko. 1970. Atmospheric lead-its relationship to traffic volume and proximity to highways. Environ. Sci. Technol. 4:318-322.

Davies, B.E. 1990. Lead. p. 177-196. In B.J. Alloway (ed.) Heavy metals in soils. John Wiley \& Sons, New York.

Doyle, M.W., E.H. Stanley, and J.M. Harbor. 2003. Channel adjustments following two dam removals in Wisconsin. Water Resour. Res. 39(1):1011 doi:10.1029/2002WR001714.

Fenneman, N.M. 1946. Physical divisions of the United States. U.S. Geological Survey special map, scale 1:7000000, 1 sheet. U.S. Geological Survey, Reston, VA.

Forstner, U., and G.T.W. Wittmann. 1981. Metal pollution in the aquatic environment. Springer-Verlag, New York.

Grosbois, C., A.J. Horowitz, J.J. Smith, and K.A. Elrick. 2001. The effect of mining and related activities on the sediment-trace element geochemistry of Lake Coeur d'Alene, Idaho, USA. Part III. Downstream effects: The Spokane River Basin. Hydrol. Processes 15:855-875.

Guy, H.P. 1969. Laboratory theory and methods for sediment analysis. 
U.S. Geological Survey Techniques of Water-Resources Investigations, Book 5, Chap. C1. U.S. Geological Survey, Lawrence, KS.

Helsel, D.R., and R.M. Hirsch. 1992. Statistical methods in water resources. Elsevier Science, Amsterdam.

High Plains Regional Climate Center. 2002. Historical data summaries [Online]. Available at www.hprcc.unl.edu (accessed 21 Aug. 2002; verified 11 July 2006).

Horowitz, A.J. 1991. A primer on sediment-trace element chemistry. 2nd ed. Lewis Publishers, Chelsea, MI.

Horowitz, A.J., K.A. Elrick, and R.P. Hooper. 1989. The prediction of aquatic sediment-associated trace element concentrations using selected geochemical factors. Hydrol. Processes 3:347-364.

Horowitz, A.J., K.A. Elrick, and J.J. Smith. 2001. Estimating suspended sediment and trace element fluxes in large river basins: Methodological considerations as applied to the NASQAN programme. Hydrol. Processes 15:1107-1132.

Jaworski, J.F. 1987. Lead. p. 3-16. In T.C. Hutchinson and K.M. Meema (ed.) Lead, mercury, cadmium, and arsenic in the environment. John Wiley \& Sons, New York.

Jordan, P.R., and J.K. Stamer (ed.) 1995. Surface water quality assessment of the lower Kansas River Basin, Kansas and Nebraskaanalysis of available data through 1986. U.S. Geological Survey Water Supply Paper 2352-B. U.S. Geological Survey, Reston, VA.

Juracek, K.E. 2003. Sediment deposition and occurrence of selected nutrients, other chemical constituents, and diatoms in bottom sediment, Perry Lake, northeast Kansas, 1969-2001. U.S. Geological Survey Water Resources Inv. Rep. 03-4025. U.S. Geological Survey, Lawrence, KS.

Juracek, K.E. 2004. Sedimentation and occurrence and trends of selected chemical constituents in bottom sediment of 10 small reservoirs, eastern Kansas. U.S. Geological Survey Scientific Inv. Rep. 2004-5228. U.S. Geological Survey, Lawrence, KS.

Juracek, K.E., and D.P. Mau. 2002. Sediment deposition and occurrence of selected nutrients and other chemical constituents in bottom sediment, Tuttle Creek Lake, northeast Kansas, 1962-99. U.S. Geological Survey Water Resources Inv. Rep. 02-4048. U.S. Geological Survey, Lawrence, KS.

Kansas Applied Remote Sensing Program. 1993. Kansas land cover database, scale 1:100000. Data Access and Support Center, Lawrence, KS.

Lagerwerff, J.V., and A.W. Specht. 1970. Contamination of roadside soil and vegetation with cadmium, nickel, lead, and zinc. Environ. Sci. Technol. 4:583-586.

MacDonald, D.D., C.G. Ingersoll, and T.A. Berger. 2000. Development and evaluation of consensus-based sediment quality guidelines for freshwater ecosystems. Arch. Environ. Contam. Toxicol. 39:20-31.

Milberg, R.P., J.V. Lagerwerff, D.L. Brower, and G.T. Biersdorf. 1980. Soil lead accumulation alongside a newly constructed roadway. J. Environ. Qual. 9:6-8.

Motto, H.L., R.H. Daines, D.M. Chilko, and C.K. Motto. 1970. Lead in soils and plants: Its relationship to traffic volume and proximity to highways. Environ. Sci. Technol. 4:231-237.

Outridge, P.M., M.H. Hermanson, and W.L. Lockhart. 2002. Regional variations in atmospheric deposition and sources of anthropogenic lead in lake sediments across the Canadian Arctic. Geochim. Cosmochim. Acta 66:3521-3531.

Page, A.L., T.J. Ganje, and M.S. Joshi. 1971. Lead quantities in plants, soil, and air near some major highways in southern California. Hilgardia 41:1-31.

Rice, K.C. 1999. Trace element concentrations in streambed sediment across the conterminous United States. Environ. Sci. Technol. 33: 2499-2504.

Schoewe, W.H. 1949. The geography of Kansas. Trans. Kans. Acad. Sci. $52: 261-333$

Shuman, J.R. 1995. Environmental considerations for assessing dam removal alternatives for river restoration. Regul. Rivers Res. Manage. 11:249-261.

Singer, M.J., and L. Hanson. 1969. Lead accumulation in soils near highways in the twin cities metropolitan area. Soil Sci. Soc. Am. Proc. 33:152-153.

Siver, P.A., and J.A. Wozniak. 2001. Lead analysis of sediment cores from seven Connecticut lakes. J. Paleolimnol. 26:1-10.

Turekian, K.K., and K.H. Wedepohl. 1961. Distribution of the elements in some major units of the earth's crust. Geol. Soc. Am. Bull. 72:175-192.

USDA-SCS. 1960. Soil survey of Brown County, Kansas. USDA Soil Conservation Service, Washington, DC.

USDA-SCS. 1977. Soil survey of Anderson County, Kansas. USDA Soil Conservation Service, Washington, DC.

USDA-SCS. 1979a. Soil survey of Johnson County, Kansas. USDA Soil Conservation Service, Washington, DC.

USDA-SCS. 1979b. Soil survey of Sedgwick County, Kansas. USDA Soil Conservation Service, Washington, DC.

USDA-SCS. 1981. Soil survey of Bourbon County, Kansas. USDA Soil Conservation Service, Washington, DC.

USDA-SCS. 1982a. Soil survey of Greenwood County, Kansas. USDA Soil Conservation Service, Washington, DC.

USDA-SCS. 1982b. Soil survey of Nemaha County, Kansas. USDA Soil Conservation Service, Washington, DC.

USEPA. 1997. The incidence and severity of sediment contamination in surface waters of the United States. Vol. 1, National sediment quality survey. EPA/823/R-97/006. USEPA, Washington, DC.

USEPA. 2000. National air pollutant emission trends, 1900-1998. EPA/454/R-00/002. USEPA, Washington, DC.

Van Metre, P.C., J.T. Wilson, E. Callender, and C.C. Fuller. 1998. Similar rates of decrease of persistent, hydrophobic and particlereactive contaminants in riverine systems. Environ. Sci. Technol. 32:3312-3317.

Wong, P.T.S., B.A. Silverberg, Y.K. Chau, and P.V. Hodson. 1978. Lead and the aquatic biota. p. 279-342. In J.O. Nriagu (ed.) The biogeochemistry of lead in the environment. Part B. Biological effects. Elsevier/North-Holland Biomedical Press, New York.

Wright, D.A., and P. Welbourn. 2002. Environmental toxicology. Cambridge Univ. Press, New York.

Zoumis, T., A. Schmidt, L. Grigorova, and W. Calmano. 2001. Contaminants in sediments-remobilisation and demobilisation. Sci. Total Environ. 266:195-202. 